Przemystaw Ogarek

Politechnika Rzeszowska im. I. Łukasiewicza.

Mariusz Ruszel

Politechnika Rzeszowska im. I. Łukasiewicza.

Pawet Węrzyn

Politechnika Rzeszowska im. I. Łukasiewicza.

\title{
Wpływ relacji politycznych Azerbejdżanu z Unią Europejską na bezpieczeństwo energetyczne
}

$\mathrm{B}$ ezpieczeństwo energetyczne, postrzegane jest jako jeden z kluczowych elementów bezpieczeństwa narodowego każdego państwa ${ }^{37}$. Stabilnie funkcjonujący sektor energetyczny zapewnia niezależność, pewność i konkurencyjność na arenie międzynarodowej. Największe mocarstwa współczesnego świata, swą potęgę w znacznym stopniu opierają o aspekty energetyczne. Analizując pojęcie bezpieczeństwa energetycznego należy przede wszystkim zaznaczyć, iż jest to dziedzina interdyscyplinarna, w której istotną rolę odgrywają aspekty geopolityczne, geoekonomiczne oraz ekologiczne $^{38}$. Najważniejszym podmiotem odpowiedzialnym za zapewnienie bezpieczeństwa energetycznego jest państwo, które wykorzystuje dostępne instrumenty i środki celem osiągnięcia swoich celów strategicznych. Zupełnie inaczej bezpieczeństwo energetyczne postrzegane jest przez eksportera oraz importera surowców energetycznych. Z perspektywy importera kluczowa jest pewność oraz ciągłość dostaw surowców energetycznych w celu pokrycia obecnego i perspektywicznego zapotrzebowania na surowce energetyczne w sposób ekonomicznie i ekologicznie uzasadniony. Największe zagrożenie dla takich państw stanowi nadmierne uzależnienie od jednego dostawcy, będące skutkiem nieodpowiednio prowadzonej polityki dywersyfikacji źródeł dostaw. Podstawą dobrze prowadzone polityki zróżnicowania źródeł i kierunków dostaw surowców energetycznych jest posiadanie odpowiednio rozbudowanej infrastruktury energetycznej. Z drugiej strony $-\mathrm{z}$ perspektywy eksporterów - bezpieczeństwo energetyczne jest to gwarancja długoterminowego, opłacalnego ekonomicznie zbytu na wydobywane produkty oraz stabilna, konkurencyjna pozycja na rynku dostawców ${ }^{39}$. Kluczowe znaczenie dla eksporterów ma nie tylko odpowiednio rozbudowana infrastruktura energetyczna, ale również kontrakty

\footnotetext{
${ }^{37}$ M. Ruszel, Paradygmat bezpieczeństwa energetycznego, [w:] Zarys teorii bezpieczeństwa państwa, red. J. Gryz, Warszawa 2016, s. 317-337.

38 M. Lewandowski, Bezpieczeństwo energetyczne w problematyce bezpieczeństwa narodowego, [w:] De Securitate et Defensione, 2019, s. 179-182.

39 J. Misiągiewicz, Bezpieczeństwo energetyczne Unii Europejskiej, [w:] Poziomy analizy stosunków Międzynarodowych, 2013 (14), s. 483-506.
} 
długoterminowe, które gwarantują stabilność zbytu na towar. Obecnie coraz większe zagrożenie dla wydobywców surowców energetycznych stanowi rozwój nowych technologii i stopniowe przechodzenie na paliwa alternatywne $\mathrm{w}$ tym szczególnie te pochodzące $\mathrm{z}$ odnawialnych źródła energii. Importerzy są silnie uzależnieni od pewnej, doskonałej konkurencyjnie podaży, natomiast eksporterzy od popytu, którego spadek oznacza brak zysków i poważne konsekwencje gospodarcze. Oznacza to, że pomiędzy tymi kategoriami państwa zachodzą nieustanne korelacje polityczne.

Celem niniejszego artykułu jest zbadanie relacji pomiędzy uzależnioną od importu gazu ziemnego Unią Europejską (UE), a poszukującym nowych rynków zbytu, Azerbejdżanem. W ujęciu podmiotowym przyjęto założenie, że najważniejszym aktorem stosunków międzynarodowych jest państwo, zaś w kontekście przedmiotowym skupiono się na gazie ziemnym. $Z$ tego względu postawiono pytanie badawcze: w jaki sposób dostawy gazu ziemnego pomiędzy Azerbejdżanem, a UE wpłyną na bezpieczeństwo energetyczne, a co za tym idzie i bezpieczeństwo narodowe podmiotów operujących na rynku europejskim. Postawiono hipotezę badawczą, że dostawy azerskiego gazu ziemnego do UE wzmocnią polityczną pozycję Turcji. W artykule zastosowanie znalazło podejście realistyczne, wykorzystano metodę statystycznej analizy dynamiki oraz dedukcji, a także technikę prognozowania.

\section{Unijny rynek gazu ziemnego}

Unia Europejska importuje 55\% zużywanej przez siebie energii. ${ }^{40}$ Zależność od zewnętrznych dostaw gazu ziemnego w UE sięga 77,9\%. W 15 państwach członkowskich uzależnienie od importu błękitnego paliwa przekracza granicę $90 \%{ }^{41} \mathrm{~W} 2019$ roku $38 \%$ gazu importowanego do UE pochodziło z Rosji, $25 \%$ z Norwegii, a $11 \%$ z Algierii. Pozostałe źródła posiadały znacznie mniejsze udziały w rynku i pochodziło z nich łącznie około $26 \%$ gazu (patrz: Diagram 1). ${ }^{42}$

\footnotetext{
${ }^{40}$ Where does our energy come from? ec.europa.eu/eurostat/cache/infographs/energy/bloc-2a.html (12.07.2020)

${ }^{41}$ Eurostat, Natural gas supply statistics - Statistics Explained, 2019, s. 4.

${ }^{42}$ Eurostat, EU imports of energy products - recent developments, ec.europa.eu/eurostat/ (14.07.20)
} 
Diagram 1. Import gazu ziemnego UE (27) - dostawcy - 2019

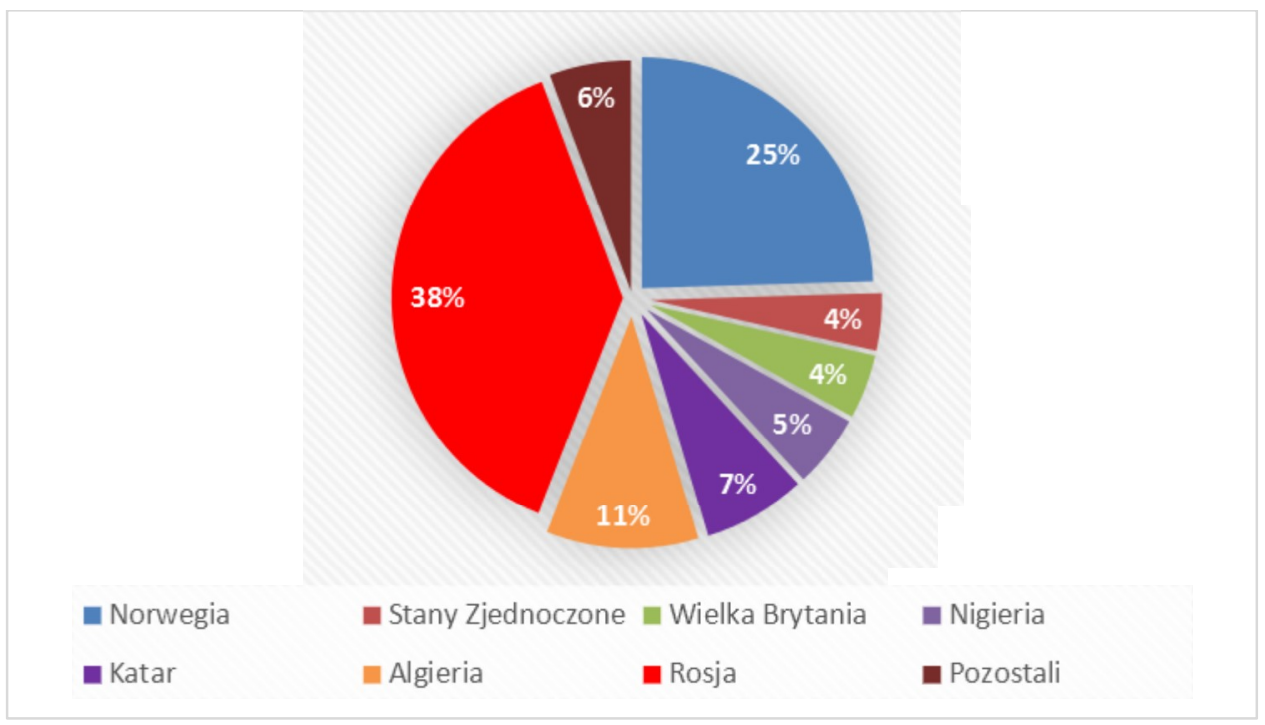

Źródło: EU imports of energy products - recent developments, ec.europa.eu/eurostat/ (14.07.20)

Unia Europejska należąca do grupy importerów, aby utrzymać silną pozycję na arenie międzynarodowej, realizuje wspólnotowe interesy strategiczne, do których zalicza się przede wszystkim: dywersyfikację źródeł dostaw, rozbudowę połączeń infrastrukturalnych; zapewnianie dostępu do stabilnych dostaw surowców energetycznych po akceptowalnej cenie; rozwój technologii energetycznych; budowanie silnego, zintegrowanego rynku energetycznego. ${ }^{43}$ Prowadząc politykę energetyczną, której celem jest osiągnięcie do roku 2050 zerowej emisji gazów cieplarnianych netto ${ }^{44}$ UE zmuszona jest do odchodzenia od wysokoemisyjnych paliw kopalnych m.in. węgla kamiennego na rzecz innych bardziej proekologicznych surowców, źródeł produkcji energii. Inwestując w nadal silnie uzależnione od warunków atmosferycznych źródła odnawialne (OZE), w momentach niedoborów energii zmuszona jest do stabilizowania systemu przy wykorzystaniu paliw konwencjonalnych. Rolę stabilizatora $\mathrm{w}$ procesie transformacji energetycznej $\mathrm{w}$ wielu państwach członkowskich stanowić ma gaz ziemny. Jako paliwo przejściowe pomiędzy węglem kamiennym i ropą naftową, a mniej emisyjnymi, paliwami gazowymi biometanem, biogazem, wodorem. ${ }^{45}$

Analizując zapotrzebowanie na gaz w państwach UE w ostatniej dekadzie, zauważyć można $12 \%$ spadek. (patrz: Tabela 1) Szacuje się, że do roku 2030 wolumen zapotrzebowania na błękitne paliwo w Unii Europejskiej będzie utrzymywał się na stabilnym poziomie, a w latach 2030 - 2050 jego wykorzystanie będzie nieznacznie malało. ${ }^{46}$ Pomimo wykazywanych predykcji spadkowych, gaz ziemny dla państw członkowskich UE, w ciągu

\footnotetext{
43 Komunikat Komisji do Parlamentu Europejskiego i Rady, Europejska strategia bezpieczeństwa energetycznego, 2014

${ }^{44}$ Croatian Presidency of the Council of the European Union, European Comission, Long-term low greenhouse gas emission development strategy of the European Union and its Member States, 2020, s. 1-4.

${ }^{45}$ CEPS Research Report, The future of gas in Europe: Review of recent studies on the future of gas, 2019, s. 36.

${ }^{46}$ Ibidem, s. 7-13.
} 
najbliższych kilkudziesięciu lat nadal będzie surowcem, posiadającym duży potencjał strategiczny. Wynika to $\mathrm{z}$ tego, iż wolumen wydobywania błękitnego paliwa ulega regresji znacznie dynamiczniej od wolumenu zapotrzebowania. W ostatniej dekadzie zmniejszył się on o blisko $40 \%\left(2010\right.$ - 183,8 $\mathrm{mld} \mathrm{m}^{3}, 2018$ - 109,2 $\left.\mathrm{mld} \mathrm{m}^{3}\right) .{ }^{47}$ Przyczyniło się do tego ograniczenie produkcji gazu ziemnego w Holandii, a do 2025 roku szacuje się dalszy spadek o kilkadziesiąt procent, za sprawą zakończenia wydobycia w potężnym holenderskim złożu Groningen. ${ }^{48}$ Projekcję zapotrzebowania na gaz ziemny oparto o obliczenie przyrostu względnego określanego wzorem: ${ }^{49}$

$$
d_{t / t^{*}}=\frac{x_{t}-x_{t *}}{x_{t *}}=\frac{\Delta_{t / t^{*}}}{x_{t^{*}}}
$$

Tabela 1. Rynek gazu ziemnego w Unii Europejskiej 2010 - 2018, 2040 (mld m3)

\begin{tabular}{|r|c|c|c|}
\hline \multicolumn{1}{|c|}{ Rok } & Zużycie & Produkcja & Import \\
\hline $\mathbf{2 0 1 0}$ & 521,3 & 183,8 & 313,9 \\
\hline $\mathbf{2 0 1 1}$ & 471 & 164,2 & 323,6 \\
\hline $\mathbf{2 0 1 2}$ & 459,1 & 153,7 & 296,7 \\
\hline $\mathbf{2 0 1 3}$ & 451,2 & 151,5 & 285,8 \\
\hline $\mathbf{2 0 1 4}$ & 401,7 & 138,2 & 261,4 \\
\hline $\mathbf{2 0 1 5}$ & 418,7 & 125,7 & 271 \\
\hline $\mathbf{2 0 1 6}$ & 449,3 & 124,7 & 287 \\
\hline $\mathbf{2 0 1 7}$ & 465,7 & 119,7 & 312,7 \\
\hline $\mathbf{2 0 1 8}$ & 458,5 & 109,2 & 401 \\
\hline $\mathbf{2 0 4 0}$ & 457 & 56 & 2,1 \\
\hline \multicolumn{4}{|c|}{ Analiza dynamiki (\%) - przyrosty względne } \\
\hline$(2010>2018)$ & $-12,05$ & $-40,59$ & 25,08 \\
\hline$(2018>2040)$ & \multicolumn{4}{|c|}{$-0,33$} & $-48,72$ & \\
\hline
\end{tabular}

Źródlo: Opracowanie wlasne na podstawie: BP, Statistical Review of World Energy 2019, s. 32-34; Oxford Economics, Global Economic Databank, www.oxfordeconomics.com/GlobalEconomic-Databank (12.07.2020)

Państwa UE w znacznej mierze uzależnione są od importu rosyjskiego gazu dostarczanego przez Gazprom, który wielokrotnie nadużywał pozycji monopolisty na unijnym rynku. ${ }^{50}$ Istotne uzależnienie od rosyjskiego gazu wynika $\mathrm{z}$ uwarunkowań geopolitycznych, które wpłynęły na odpowiednią budowę infrastruktury gazowej oraz zawarcie długoterminowych kontraktów gazowych. ${ }^{51}$ Federacja Rosyjska jako gazowy

\footnotetext{
${ }^{47}$ BP, Statistical Review of World Energy 2019, s. 32-34.

${ }^{48}$ International Energy Agency, Gas 2020, s. 43.

${ }^{49}$ G. Juszczak-Szumacher, Analiza dynamiki zjawisk [w:] Podstawy statystyki. Wydanie 2, 2009, s. 198-201 Symbol t* jest numerem okresu, do którego porównujemy wartości danego okresu t. Dla uzyskania procentowego wyniku prognozy, jej wartości należy przemnożyć *100\%. Jeżeli przyrost jest dodani, oznacza to, że w okresie t nastąpił wzrost badanej wartości, ujemny - spadek badanej wartości, wynosi 0 - brak zmian.

${ }^{50}$ G. O. Austvik, The Energy Union and security-of-gas supply, Energy Policy nr 96, s. 373-374. A. Mikulska, Gazprom and Russian Natural Gas Policy in the First Two Decades of the 21st Century, Orbis nr 64, s. 403-420.

${ }^{51}$ Y. Fedorov, Continuity and change in Russia's policy toward Central and Eastern Europe, Communist and Post-Communist Studies nr 46, s. 315-326.
} 
potentat, opierający około $25 \%$ PKB na zyskach zdobytych dzięki eksportowi surowców energetycznych $^{52}$ dąży do utrzymania swojej dominującej pozycji na rynku europejskim, prowadząc działania mające na celu rozszerzanie rosyjskich wpływów oraz paraliżowanie realizacji założeń unijnej polityki dywersyfikacji źródeł dostaw. Konflikt interesów obu podmiotów, wpływa na to, że projekty na rzecz zwiększenia zróżnicowania grupy eksporterów gazu ziemnego do UE są bardzo często sabotażowane poprzez formalne i nieformalne działania Federacji Rosyjskiej. ${ }^{53}$

\section{Azerski rynek gazu ziemnego}

Jednym z państw posiadających potencjał na poprawę dywersyfikacji źródeł dostaw gazu ziemnego do UE, a co za tym idzie zwiększenie poziomu jej bezpieczeństwa energetycznego jest Azerbejdżan. ${ }^{54}$ Państwo to ponad 90\% zysków z eksportu uzyskuje właśnie poprzez sprzedaż paliw kopalnych, a w szczególności ropy naftowej i gazu ziemnego. ${ }^{55}$ Potwierdza to dynamika zmian na rynku ropy naftowej oraz wzrastające państwowe zapotrzebowanie na ten surowiec $(2010-2018) .{ }^{56} \mathrm{~W} 2020$ r. proces ten spowolnił wskutek globalnej pandemii COVID-19. Należy zauważyć, że w Azerbejdżanie modernizuje się strukturę wydobywczą, skupiając się szczególnie na rozbudowie sektora gazowego.

Historia wydobycia błękitnego paliwa w Azerbejdżanie sięga końcówki lat 60, XX wieku. Jednakże dopiero od 2007 roku sektor gazowy zaczął się dynamicznie rozwijać, co umożliwiło rozpoczęcie sprzedaży błękitnego paliwa. Obecnie gaz ziemny staje się najważniejszym towarem eksportowym. Azerbejdżan dysponuje sporymi złożami naturalnymi, których potencjał określa się na $2100 \mathrm{mld} \mathrm{m}^{3}{ }^{57}$ Podkreśla się, że ich zasobność może być jeszcze znacznie wyższa. (patrz: Tabela 2)

Tabela 2. Perspektywicznie złoża gazu ziemnego

\begin{tabular}{|c|c|}
\hline Nazwa złoża & Szacowane zasoby \\
\hline Absheron & $350 \mathrm{mld} \mathrm{m}^{3}$ \\
\hline Araz, Alov, Sharg & $700 \mathrm{mld} \mathrm{m}^{3}$ \\
\hline ACG & $280 \mathrm{mld} \mathrm{m}^{3}$ \\
\hline Umid & $200 \mathrm{mld} \mathrm{m}^{3}$ \\
\hline Babek & $400 \mathrm{mld} \mathrm{m}^{3}$ \\
\hline Shafag-Asiman & $500 \mathrm{mld} \mathrm{m}^{3}$ \\
\hline
\end{tabular}

Źródlo: F. J. Hasanov, C. Mahmudlu, K. Deb, S. Abilov, O. Hasanov, The role of Azeri natural gas in meeting European Union energy security needs, [w:] Energy Strategy Reviews, 2020, s. 6.

\footnotetext{
${ }^{52}$ K. Falkowski, Polityka surowcowa wybranych krajów poradzieckich a ich konkurencyjność w handlu międzynarodowym, [w:] Zeszyty Naukowe - Uniwersytet Ekonomiczny w Krakowie, 2019, s. 70.

${ }^{53}$ M. Ruszel, Analiza wybranych nieformalnych sposobów wpływania na politykę energetyczną UE - na przykładzie Federacji Rosyjskiej, "Bezpieczeństwo Narodowe", nr 35/2015, BBN, Warszawa 2015, s. 112-115.

${ }^{54}$ Komunikat Komisji do Parlamentu..., op. cit.

${ }^{55}$ F. J. Hasanov, C. Mahmudlu, K. Deb, S. Abilov, O. Hasanov, The role of Azeri natural gas in meeting European Union energy security needs, [w:] Energy Strategy Reviews, 2020, s. 6.

${ }^{56}$ BP, op. cit., s. 20.

${ }^{57}$ Ibidem, s. 30.
} 
W Azerbejdżanie głównymi wydobywcami gazu ziemnego są: azerski koncern SOCAR (State Oil Company of the Azerbaijan Republic), międzynarodowe konsorcjum AIOC (Azerbaijan International Operating Company), w którym udziały posiadają Azerbejdżan, Wielka Brytania, Turcja, USA, Węgry, Japonia, a także koncern Shah Deniz. Azerbejdżan prowadzi politykę energetyczną w obszarze wydobycia w taki sposób, aby zachować kontrolę nad rynkiem krajowym. Dlatego inwestować w azerski rynek surowcowy mogą tylko spółki joint venture lub firmy na podstawie umów o rozdziale produkcji, które muszą być potwierdzone przez parlament. W ten sposób, państwo sprawuje skuteczną kontrolę nad sektorem wydobywczym i czerpie korzyści finansowe z eksportu jego produktów. ${ }^{58}$ Należy dodać, że od 2010 roku wolumen eksportu gazu ziemnego w Azerbejdżanie wzrósł o $60,1 \%{ }^{59}$, a krajowe wydobycie o ponad 15\%. (patrz: Tabela 3).

Tabela 3. Rynek gazu ziemnego w Azerbejdżanie - 2010 - 2018 (mld m3)

\begin{tabular}{|c|c|c|c|}
\hline Rok & Zużycie & Produkcja & Eksport \\
\hline 2010 & 8,1 & 16,67 & 6,19 \\
\hline 2011 & 8,9 & 16,36 & 6,82 \\
\hline 2012 & 9,4 & 17,24 & 6,62 \\
\hline 2013 & 9,4 & 17,9 & 7,31 \\
\hline 2014 & 9,9 & 18,83 & 8,1 \\
\hline 2015 & 11,1 & 19,24 & 8,15 \\
\hline 2016 & 10,9 & 18,72 & 8,05 \\
\hline 2017 & 10,6 & 18,19 & 8,86 \\
\hline 2018 & 10,8 & 19,21 & 9,91 \\
\hline \multicolumn{4}{|c|}{ Analiza dynamiki (\%) - przyrosty względne } \\
\hline$(2010>2018)$ & 33,33 & 15,24 & 60,1 \\
\hline
\end{tabular}

Źródlo: Opracowanie wlasne na podstawie: BP, Statistical Review of World Energy 2019, 32-34.; Azerbaijan Statistical Information Service, Commodity balance of natural gas, www.azstat.org/portal/tbIInfo/TbIInfoList.do (14.07.20)

Pomimo dużych wartości przyrostów względnych w latach 2010 - 2018 , w odniesieniu do produkcji i eksportu ogromny potencjał surowcowy nie jest w pełni wykorzystywany. Ograniczona przepustowość gazociągów uniemożliwia przesył azerskiego gazu ziemnego do zagranicznych klientów i wstrzymuje szansę rozwoju. W związku z tym głównym interesem Azerbejdżanu jest rozbudowa infrastruktury przesyłowej i rozszerzenie sfery potencjalnych odbiorców. Realizacja tego strategicznego celu pozwoliłaby na zwiększenie zysków z eksportu oraz budowę silnej pozycji politycznej na międzynarodowym rynku energetycznym.

\section{Połączenie gazowe Azerbejdżan - Unia Europejska}

\footnotetext{
${ }^{58}$ K. Falkowski, op. cit., s. 71.

59 Azerbaijan Statistical Information Service, Commodity balance of natural gas (2010 - 2018), www.azstat.org/portal/tblInfo/TblInfoList.do (14.07.20)
} 
Największe obecnie eksploatowane pole gazowe - Shah Deniz, którego zasoby szacuje na ponad $1000 \mathrm{mld}^{3}$ gazu $^{60}$ oraz perspektywiczne projekty znacznie zwiększające możliwości wydobywcze Azerbejdżanu - Shah Deniz 2 i Shah Deniz 3 stanowią podstawę do budowy Południowego Korytarza Gazowego, w skład którego wchodzić będą krótsze magistrale: Gazociąg Południowokaukaski (zwany również Baku-Tiblisi-Erzurum), TANAP i TAP (patrz: Mapa 1). Obecnie wszystkie elementy projektu są już na etapie realizacji. ${ }^{61}$

UE podjęła decyzję o wpisaniu gazociągów TANAP i TAP na listę projektów PCI (Project of Common Interest), które mają kluczowe znaczenie dla łączenia systemów energetycznych w krajach Unii Europejskiej i realizacji założeń dywersyfikacji źródeł dostaw energii.). W konsekwencji projekt zyska wsparcie ze środków UE. ${ }^{62}$

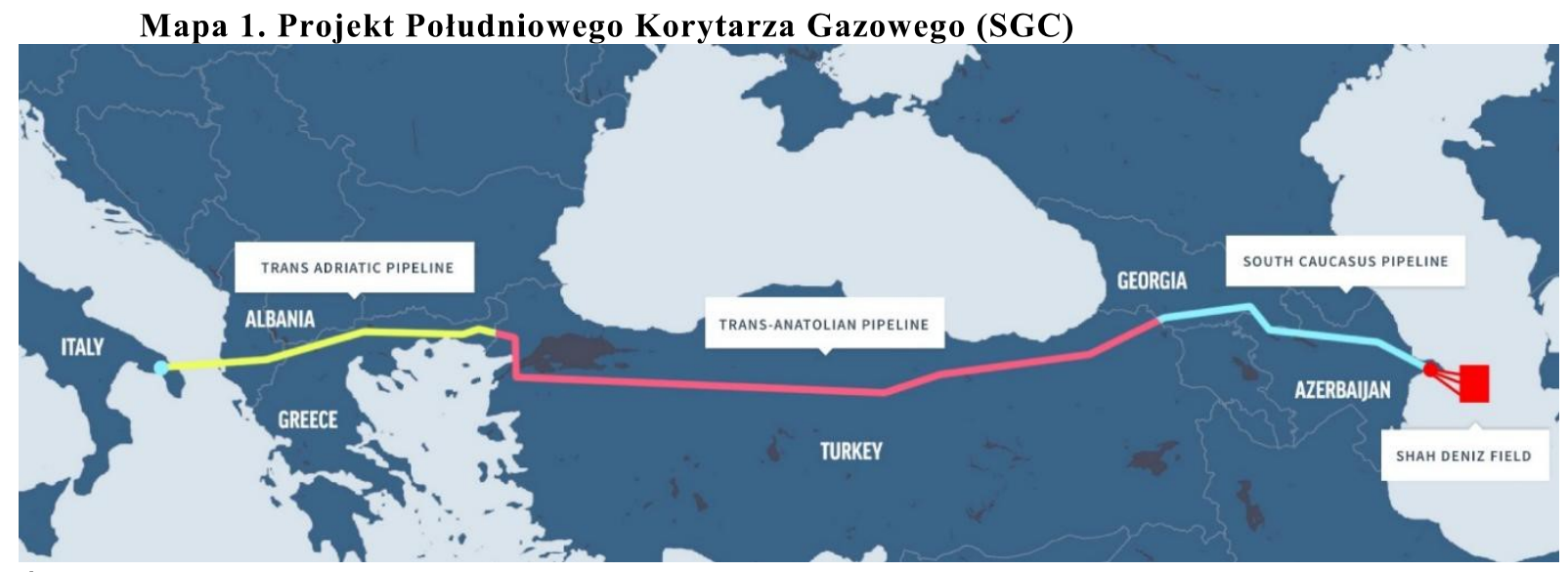

Źródło: What is Southern Gas Corridor? www.sgc.az/en (14.07.20)

Pierwszym elementem Południowego Korytarza Gazowego jest gazociąg BakuTbilisi-Erzurum (SCP), który powstał w celu przesyłu gazu wydobywanego ze złoża Shah Deniz położonego w azerbejdżańskim sektorze Morza Kaspijskiego do Gruzji i Turcji. Jego długość wynosi $692 \mathrm{~km}$. Dostawy tym gazociągiem rozpoczęły się w drugiej połowie 2006 roku. Aktualnie realizowany przesył gazu to ok. $7 \mathrm{mld} \mathrm{m}^{3}$ rocznie, przy czym rozbudowa SCP o drugą nitkę, ma zwiększyć przepustowość o kolejne $16 \mathrm{mld}^{3}{ }^{3}$. Siedem krajowych i międzynarodowych firm energetycznych jest partnerami w rozwoju Rurociągu Południowego Kaukazu i projektu Shah Deniz ${ }^{64}$.

60 Southern Gas Corridor, Delivering Azerbaijani Gas to Europe www.delegate.com/content/annualmeeting/2016/documents/Azerbaijan-Afgan\%20Isayev.pdf (dostęp: 16.07.2020)

${ }^{61}$ M. Siddi, The Southern Gas Corridor: Prospects and Challenges for EU Foreign Policy [w:] Caucasus Analytical Digest, 2019, s. 8-9.

${ }^{62}$ IENE, European Commission to Give Financial Aid to TANAP, www.iene.eu/european-commission-to-givefinancial-aid-to-tanap-p2834.html (dostęp: 16.07.2020)

${ }^{63}$ BP Georgia, South Caucasus Pipeline Project, www.bp.com/en_ge/georgia/home/who-we-are/scp.html (dostęp:16.07.2020)

${ }^{64}$ Udziałowcami gazociągu SCP są: BP (28,8\%)- Wlk. Brytania, TPAO (19\%) - Turcja, AzSCP (10\%) Azerbejdżan, SGC Midstream (6,7\%) - Azerbejdżan , PETRONAS (15,5\%) - Malezja, LUKOIL (10,0\%) Rosja, NICO (10\%) - szwajcarska spółka zależna Irańskiej spółce rządowej 
Drugim elementem Południowego Korytarza Gazowego jest Gazociąg Transanatolijski (TANAP), który swój początek ma na granicy turecko-gruzińskiej ${ }^{65}$. Został on uruchomiony w listopadzie 2019 roku i jest najdłuższym elementem Południowego Korytarza Gazowego ${ }^{66}$. Przebiega przez 20 tureckich prowincji, jego długość wynosi ponad $1800 \mathrm{~km}$, a przepustowość w pierwszej fazie to $16 \mathrm{mld} \mathrm{m}^{3}$. Z pełnego wolumenu, aż $6 \mathrm{mld} \mathrm{\textrm {m } ^ { 3 }}$ (ok. 14\% zużycia Turcji w 2019 roku) jest zarezerwowane przez stronę turecką, a $10 \mathrm{mld} \mathrm{m}^{3}$ ma trafić do Unii Europejskiej ${ }^{67}$. Do 2023 roku zdolność przesyłowa ma być zwiększona do

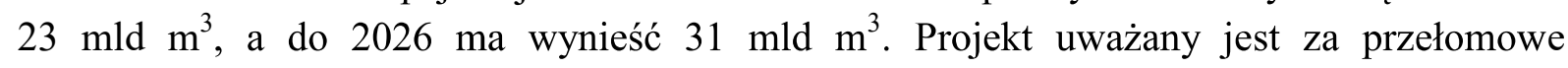
przedsięwzięcie energetyczne $\mathrm{w}$ regionie Bliskiego Wschodu ze względu na połączenie azerskiego rynku gazu ziemnego z tureckim. Nazywany Jedwabnym Szlakiem Energii, wybudowany w niespełna 3 lata od rozpoczęcia prac budowlanych ma być przeciwwagą dla dominacji rosyjskiego surowca $\mathrm{w}$ tym obszarze ${ }^{68}$. Koszt przedsięwzięcia planowo miał wynieść ok. 12 mld USD, lecz finalnie udało się obniżyć koszty realizacji projektu o ok. 5 mld USD, czyli $40 \%$ początkowych założeń.

Trzecim elementem Południowego Korytarza Gazowego jest Gazociąg Transadriatycki (TAP) ${ }^{69}$. Jest to ostatni odcinek, łączący magistralę TANAP z odbiorcami gazu w Unii Europejskiej. Przebiegać będzie przez Grecję, Albanię i Morze Adriatyckie. Jego długość wynosi $878 \mathrm{~km}$, z czego $105 \mathrm{~km}$ to odcinek na dnie morza. Zdolność przesyłowa to

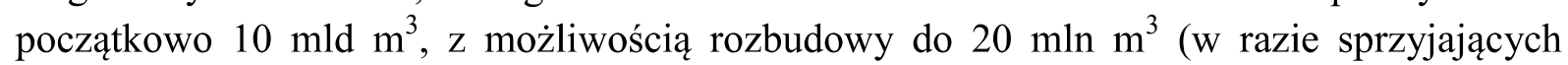
odkryć złóż na Morzu Kaspijskim). Koszt przedsięwzięcia to ok. 4,5 mld euro przy dużym wsparciu Europejskiego Banku Odbudowy i Rozwoju oraz Europejskiego Banku Centralnego. Projekt jest już po wstępnych testach na 2 kilometrowym greckim odcinku gazociągu. Na koniec czerwca 2020 roku, wykonanie projektu jest oszacowane przez grupę TAP-AG na $96,4 \%{ }^{70}$.

Finalnie, koszt całego projektu Południowego Korytarza Gazowego to ok. $45 \mathrm{mld}$ USD. Wolumen przesyłu azerskiego gazu do Unii Europejskiej w pierwszej fazie, nie będzie zbyt istotny z punktu widzenia całej Unii Europejskiej, gdyż przesyłany gaz będzie stanowił ok. $2 \%$ rocznego zużycia UE. Jednak realizację tej koncepcji, należy rozpatrywać wielopłaszczyznowo z punktu widzenia: państwa eksportera, państwa tranzytowego, państwa importera, państw Unii Europejskiej oraz Federacji Rosyjskiej.

\section{Znaczenie Południowego Korytarza Gazowego}

\footnotetext{
${ }^{65}$ Udziałowcami gazociągu TANAP są: Azerbejdżański SOCAR (51\%), turecki operator gazociągów BOTAS (30\%), BP (12\%), SOCAR Turcja (7\%).

66 Turkey and Azerbaijan mark completion of TANAP pipeline to take gas to Europe www.reuters.com/article/us-turkey-energy-tanap/turkey-and-azerbaijan-mark-completion-of-tanap-pipeline-totake-gas-to-europe-idUSKBN1Y40CP (dostęp: 16.07.2020)

${ }^{67}$ Natural gas consumption in Turkey from 2005 to 2019, www.statista.com/statistics/703684/natural-gasconsumption-turkey/ (dostęp: 16.07.2020)

${ }^{68}$ TANAP now fully ready to deliver natural gas to Europe, www.dailysabah.com/energy/2019/07/02/tanapnow-fully-ready-to-deliver-natural-gas-to-europe (dostęp:16.07.2020)

${ }^{69}$ Udziałowcami gazociągu TAP są: BP (20\%), SOCAR (20\%), Snam (20\%), Fluxys (19\%), Enagas (16\%) i Axpo (5\%).

${ }^{70}$ TAP, Project progres, www.tap-ag.com/pipeline-construction/project-progress (dostęp:16.07.2020)
} 
Obecne rozwiązanie Południowego Korytarza Gazowego nie jest spełnieniem pierwotnego założenia Unii Europejskiej, która w pierwszej dekadzie XXI wieku, forsowała projekt Nabucco, zakładającego przesył gazu ziemnego $\mathrm{z}$ Iranu oraz Gazociągu

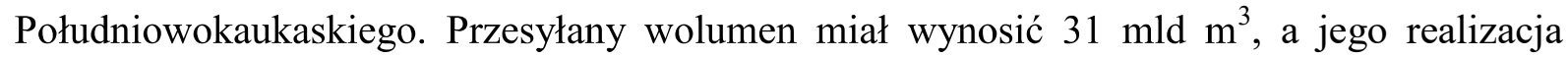
miała zostać zakończona w 2015 roku. Głównym założeniem Nabucco były dostawy gazu do Europy Południo-Wschodniej i Środkowej oraz kontrola transportu gazu przez państwa europejskie. Jednak kiedy koncepcja upadła, swoją szansę wykorzystali Azerowie i Turcy, realizując budowę gazociągów TAP i TANAP. W ten sposób, Azerbejdżan jako państwo eksporter stał się dostawcą gazu ziemnego na rynek turecki, a po ukończeniu TAP również na rynek europejski ${ }^{71}$.

Z punktu widzenia państwa eksportera, Azerbejdżan zapewnia sobie rynek zbytu w obszarach, które do tej pory były uzależnione od dostaw z Federacji Rosyjskiej. Pierwszy region, czyli Turcja gdzie ponad połowa importowanego paliwa pochodzi z Rosji, a drugi to obszar Unii Europejskiej, gdzie rosyjski gaz stanowi około 40\% zużycia. Taki stan rzeczy zapewnia Azerbejdżanowi stałych odbiorców, którzy dbają o swoje bezpieczeństwo energetyczne poprzez dywersyfikację dostaw paliw.

Rola państw tranzytowych na szlaku Południowego Korytarza Gazowego jest niemniej istotna niż samego państwa eksportera. Korzyści płynące z przebiegu infrastruktury przez Gruzję i Turcję pozwolą tym państwom czerpać zyski zarówno w obszarze ekonomicznym jak i bezpieczeństwa państwa. Warto nadmienić, że wymiar ekonomiczny państwa tranzytowego $\mathrm{z}$ dobrze zdywersyfikowanymi źródłami dostaw, daje korzyści bezpośrednie i pośrednie. Do bezpośrednich można zaliczyć opłatę tranzytową i możliwość dywersyfikowania dostaw zapewniając bezpieczeństwo energetyczne, a pośrednie to możliwość negocjacji cen za surowiec ze względu na urozmaicony koszyk możliwych źródeł dostaw surowca.

Wydaje się, że największym wygranym realizacji Korytarza Południowego jest właśnie Turcja. Wysokie zapotrzebowanie na gaz ziemny i dotychczasowy brak alternatywnych źródeł dostaw, spowodował że na przestrzeni kilku lat, Turcja stała się najważniejszym punktem na energetycznej mapie Eurazji ze względu na budowę Gazociągu TANAP, Turkishstream i rozwojowi infrastruktury odbiorczej skroplonego gazu LNG. Dążenia Turcji do odgrywania ważnej roli na arenie międzynarodowej poprzez zwiększenie bezpieczeństwa energetycznego i stania się hubem gazowym w perspektywie krótkookresowej, są jak najbardziej realne ${ }^{72}$.

Planowana przepustowość gazociągu w pierwszej fazie jest ilością znikomą w kontekście całego zapotrzebowania dla Unii Europejskiej. W wymiarze energetycznym, ten gazociąg będzie jednak nowym źródłem i kierunkiem dostaw, który wpłynie na rywalizację na rynek gazu ziemnego w Europie.

Kontekst dostaw gazu z Południowego Korytarza Gazowego dla Unii Europejskiej jest złożony, rozkłada się na trzy płaszczyzny. Pierwszy wymiar to znaczenie dla całej Unii Europejskiej, czyli magistrala interpretowana jako projekt strategiczny ze względu na

\footnotetext{
${ }^{71}$ A. Jarosiewicz, Poludniowy Korytarz Gazowy Azersko-turecki projekt w rozgrywce Rosji i UE, [w:] Punkt widzenia nr 54, Ośrodek Studiów Wschodnich, Warszawa 2015, s. 17-20.

${ }^{72}$ Turkish Stream przegrywa z LNG, biznesalert.pl/turkish-stream-spadek-dostaw-gaz-energetyka-turcja-rosja/ (dostęp: 17.07.2020)
} 
realizację polityki energetycznej Unii Europejskiej w zakresie dywersyfikacji źródeł dostaw gazu ziemnego i korzystny wpływ tego źródła na rynek dostawców do $\mathrm{UE}^{73}$.

Drugi wymiar, to konflikt grup interesów państw w Unii Europejskiej. Otóż, inaczej do tego kierunku dostaw podchodzą państwa, które będą odbiorcami surowca z Azerbejdżanu, czyli Włochy, Grecy czy Bułgarzy, a inaczej państwa które potencjalnie mogłyby dostarczyć gaz do tych państw, ale $\mathrm{z}$ innego kierunku.

Trzeci wymiar, to partykularne interesy docelowych państw, które będą importować surowiec z tego gazociągu. Państwa takie jak Włochy, Grecja czy Bułgaria, importują od 30 do $90 \%$ własnego zapotrzebowania z Federacji Rosyjskiej. Potencjalnie, jest to szansa na realną dywersyfikację dostaw (zwłaszcza dla Bułgarii) i zmniejszenia siły wpływu wschodniego monopolisty na europejski rynek gazu.

\section{Wnioski}

Unia Europejska stoi przed poważnymi wyzwaniami w obszarze gazu ziemnego, w związku ze spadającym wydobyciem własnym i utrzymującym się zużyciem tego surowca na terenie UE. Podejmowane działania polityczne wpisujące się w założenia polityki energetycznej, czyli zapewnienia ciągłości dostaw energii i dywersyfikacja ich źródeł, są działaniami priorytetowymi na nadchodzące lata. Realizacja projektów infrastrukturalnych, które będą stanowić alternatywę dla dostaw gazu ziemnego z Federacji Rosyjskiej, a przede wszystkim nowe połączenie $\mathrm{z}$ Azerbejdżanem zapewni zwiększenie poziomu konkurencyjności na rynku gazu ziemnego i poprawi poziom bezpieczeństwa energetycznego całej Unii Europejskiej. Jednak w tym przypadku, należy zauważyć, że Korytarz Południowy rozwiązuje problem bezpieczeństwa energetycznego, narodowego (a w zasadzie dywersyfikacji źródeł dostaw) konkretnych państw.

Dostawy gazu ziemnego z Azerbejdżanu do UE wpłyną negatywnie na pozycję Federacji Rosyjskiej jako dostawcy. Osłabią wpływy Rosjan w Europie Południowej i utrudnią realizację projektów mających na celu zwiększenie rosyjskich udziałów w tamtym rejonie. $\mathrm{Z}$ pewnością oczekiwać, można silnego sprzeciwu rosyjskiego i dużej rywalizacji pomiędzy, potencjalnymi eksporterami gazu ziemnego na południu Europy.

Z perspektywy Azerbejdżanu, Południowy Korytarz Gazowy jest elementem realizacji ich energetycznych interesów. Azerowie kierując się zyskiem ekonomicznym zapewnią dostawy surowca spoza dotychczasowych kierunków do Turcji i Unii Europejskiej. Uzyskanie nowych odbiorców wpłynie pozytywnie pozycję polityczną Azerbejdżanu jako dostawcy gazu.

Jednak należy uwzględnić, iż zdobywanie udziałów w unijnym rynku może prowadzić do potencjalnych zagrożeń dla bezpieczeństwa narodowego Azerbejdżanu, głównie za sprawą działań ze strony Federacji Rosyjskiej. Z punktu widzenia Federacji Rosyjskiej, Południowy Korytarz Gazowy jest projektem, który w początkowej fazie nie wydawał się być zagrożeniem dla dostaw Gazpromu do Turcji. Jednak w obliczu budowy i uruchomienia Gazociągu TANAP, sytuacja ta się zmieniła w konsekwencji czego zauważalny jest spadek importu surowca z Federacji Rosyjskiej do Turcji. Zatem z perspektywy Rosji, projekt jest

\footnotetext{
${ }^{73}$ A. Jarosiewicz, op. cit., s. 20.
} 
niepożądany, wpłynął negatywnie na jeden z ich rynków zbytu, deprecjonując ich pozycję w regionie. $\mathrm{W}$ ten sposób pozytywnie została zweryfikowana hipoteza badawcza.

\section{Streszczenie:}

Bezpieczeństwo energetyczne, postrzegane jest jako jeden z kluczowych elementów bezpieczeństwa narodowego każdego państwa. Największe mocarstwa współczesnego świata, swą potęgę w znacznym stopniu opierają o aspekty energetyczne. Jednym ze strategicznych surowców odgrywających priorytetową rolę na rynku energetycznym jest gaz ziemny. Panująca w sektorze gazowym państwowa rywalizacja, prowadzi do konfliktów interesów między tzw. państwami importerami, a eksporterami. W niniejszym opracowaniu podjęto analizę geopolitycznego znaczenia integracji energetycznej pomiędzy Unią Europejską a Azerbejdżanem. $Z$ tego względu postawiono pytanie badawcze: w jaki sposób handel gazem ziemnym pomiędzy Azerbejdżanem, a UE wpłynie na bezpieczeństwo energetyczne, a co za tym idzie i bezpieczeństwo narodowe podmiotów operujących na rynku europejskim. $\mathrm{W}$ artykule zastosowano podejście realistyczne, wykorzystano metodę statystycznej analizy dynamiki oraz dedukcji, a także technikę prognozowania.

\section{Słowa kluczowe:}

bezpieczeństwo energetyczne, Azerbejdżan, dywersyfikacja źródeł dostaw, gaz ziemny

\section{Key words:}

energy security, Azerbaijan, diversification of supply sources, natural gas

\section{Bibliografia:}

1. Austvik, O. G., The Energy Union and security-of-gas supply, Energy Policy nr 96.

2. Azerbaijan Statistical Information Service, Commodity balance of natural gas (2010 2018), www.azstat.org/portal/tblInfo/TblInfoList.do (14.07.20).

3. BP Georgia, South Caucasus Pipeline Project, www.bp.com/en_ge/georgia/home/who-we-are/scp.html (dostęp:16.07.2020).

4. BP Statistical Review of World Energy 2019.

5. CEPS Research Report, The future of gas in Europe: Review of recent studies on the future of gas, 2019.

6. Croatian Presidency of the Council of the European Union, European Comission, Long-term low greenhouse gas emission development strategy of the European Union and its Member States, 2020.

7. Eurostat, EU imports of energy products - recent developments, ec.europa.eu/eurostat/ (14.07.2020).

8. Eurostat, Natural gas supply statistics - Statistics Explained, 2019. 
9. Falkowski K., Polityka surowcowa wybranych krajów poradzieckich a ich konkurencyjność $w$ handlu międzynarodowym, [w:] Zeszyty Naukowe - Uniwersytet Ekonomiczny w Krakowie, 2019.

10. Fedorov Y., Continuity and change in Russia's policy toward Central and Eastern Europe, Communist and Post-Communist Studies nr 46.

11. Hasanov F. J., Mahmudlu C., Deb K., Abilov S., Hasanov O., The role of Azeri natural gas in meeting European Union energy security needs, [w:] Energy Strategy Reviews, 2020.

12. IENE, European Commission to Give Financial Aid to TANAP, www.iene.eu/european-commission-to-give-financial-aid-to-tanap-p2834.html (dostęp: 16.07.2020).

13. International Energy Agency, Gas 2020.

14. Jarosiewicz A., Południowy Korytarz Gazowy Azersko-turecki projekt w rozgrywce Rosji i UE, [w:] Punkt widzenia nr 54, Ośrodek Studiów Wschodnich, Warszawa 2015.

15. Juszczak-Szumacher G., Analiza dynamiki zjawisk [w:] Podstawy statystyki. Wydanie 2, 2009.

16. Lewandowski M., Bezpieczeństwo energetyczne $w$ problematyce bezpieczeństwa narodowego, [w:] De Securitate et Defensione. O Bezpieczeństwie i Obronności, 2019.

17. Mikulska A., Gazprom and Russian Natural Gas Policy in the First Two Decades of the 21st Century, Orbis nr 64.

18. Misiągiewicz J., Bezpieczeństwo energetyczne Unii Europejskiej, [w:] Poziomy analizy stosunków Międzynarodowych, 2013 (14).

19. Natural gas consumption in Turkey from 2005 to 2019, www.statista.com/statistics/703684/natural-gas-consumption-turkey/ (dostęp: 16.07.2020).

20. Ruszel M., Analiza wybranych nieformalnych sposobów wpływania na politykę energetyczną UE - na przykładzie Federacji Rosyjskiej, "Bezpieczeństwo Narodowe", nr 35/2015, BBN, Warszawa 2015.

21. Ruszel M., Paradygmat bezpieczeństwa energetycznego, [w:] Zarys teorii bezpieczeństwa państwa, red. J. Gryz, Akademia Obrony Narodowej, Warszawa 2016.

22. Siddi M., The Southern Gas Corridor: Prospects and Challenges for EU Foreign Policy [w:] Caucasus Analytical Digest, 2019.

23. Southern Gas Corridor, Delivering Azerbaijani Gas to Europe www.delegate.com/content/annualmeeting/2016/documents/AzerbaijanAfgan\%20Isayev.pdf (dostęp: 16.07.2020).

24. TANAP now fully ready to deliver natural gas to Europe, www.dailysabah.com/energy/2019/07/02/tanap-now-fully-ready-to-deliver-naturalgas-to-europe (dostęp:16.07.2020).

25. TAP, Project progres, www.tap-ag.com/pipeline-construction/project-progress (dostęp:16.07.2020). 
26. Turkey and Azerbaijan mark completion of TANAP pipeline to take gas to Europe www.reuters.com/article/us-turkey-energy-tanap/turkey-and-azerbaijan-markcompletion-of-tanap-pipeline-to-take-gas-to-europe-idUSKBN1Y40CP (dostęp: 16.07.2020).

27. Turkish Stream przegrywa z LNG, biznesalert.pl/turkish-stream-spadek-dostaw-gazenergetyka-turcja-rosja/ (dostęp: 17.07.2020).

28. Where does our energy from? ec.europa.eu/eurostat/cache/infographs/energy/bloc-2a.html (12.07.2020). 